Linguista: Jurnal IImiah Bahasa, Sastra, dan Pembelajarannya

Vol.3, No.1, Juni 2019, hal 1 - 11

ISSN (print): 2579-8944; ISSN (online): 2579-9037

Avaliable online at: http://e-journal.unipma.ac.id/index.php/linguista

\title{
Peningkatan Keterampilan Menulis Eksposisi Melalui Penerapan Metode Team Assisted Individualization Pada Siswa SMA Muhammadiyah 2 Cepu Kabupaten Blora
}

\author{
Ani Widiastuti \\ SMA Muhamadiyah 2 Cepu Kabupaten Blora, Indonesia \\ e-mail: aniwidiastuti2310@gmail.com
}

\begin{abstract}
Abstrak
Penelitian ini bertujuan untuk: (1) meningkatkan kualitas proses pembelajaran menulis eksposisi, dan (2) meningkatkan keterampilan menulis eksposisi siswa melalui penerapan metode Team Assisted Individualization pada siswa kelas X IPA 2 SMA Muhammadiyah 2 Cepu Kabupaten Blora. Metode penelitian yang digunakan deskriptif kualitatif. Penelitian ini merupakan Penelitian Tindakan Kelas (PTK). Teknik pengumpulan data meliputi pengamatan, pemberian tugas, wawancara mendalam, dan analisis dokumen. Pelaksanaan penelitian dimulai dari survei awal, siklus I sampai siklus III. Setiap siklus terdiri dari empat tahap, yakni: (1) perencanaan tindakan; (2) pelaksanaan tindakan; (3) observasi tindakan; dan (4) analisis dan refleksi. Hasil penelitian dapat disimpulkan bahwa penerapan metode Team Assisted Individualization dapat meningkatkan kualitas proses pembelajaran menulis eksposisi dan meningkatkan keterampilan menulis eksposisi pada siswa kelas X IPA 2 SMA Muhammadiyah 2 Cepu Kabupaten Blora. Pada Prasiklus $12 \%$ yang tuntas. Siklus I keterampilan menulis eksposisi mencapai $38,46 \%$, Siklus II mencapai $69 \%$ dan siklus III mencapai $81 \%$.
\end{abstract}

Kata kunci: Keterampilan Menulis Eskposisi; Team Assisted Individualization

\section{The Improvement of Students' Writing Exposition Text Using Team Assisted Individualization at SMA Muhammadiyah 2 Cepu Kabupaten Blora}

\begin{abstract}
Accordingly, this study aims at (1) improving the learning-process quality in writing exposition text; and (2) improving skill of writing exposition text using Team Assisted Individualization method for students of SMA Muhammadiyah 2 Cepu Kabupaten Blora class X IPA 2. This was a classrrom action research. The sources of the study were the observation from learning process, information, and documentation. Observation, test, depth interview, and document analysis were the techniques employed in collecting the data. The study was begun from survey, cycle I to cycle III. Every cycle consisted of four stages; (1) planning; (2) action; (3) observation; and (4) analysis and reflection. From the findings, it can be concluded that the implementation of Team Assisted Individualization can improve the students' learning process quality in writing exposition text as well as the students' skill of writing exposition text at SMA Muhammadiyah 2 Cepu Kabupaten Blora class X IPA 2. The improvement of the quality of learning process is significant from both students and teacher's perfomances. The improvement of students' skill in writing exposition text is significant viewed from the number of students who passed the minimum score. In Pracycle $12 \%$, in cycle I,
\end{abstract}


the students pass the score at $38,46 \%$. In cycle II, it improves to $69 \%$ In cycle III, it becomes $81 \%$ passing the minimum score.

Keywords: Skill of writing exposition text; Team Assisted Individualization

\section{Pendahuluan}

Pembelajaran bahasa di sekolah menitikberatkan pada empat keterampilan berbahasa. Keterampilan tersebut meliputi keterampilan menyimak, berbicara, membaca, dan menulis. Keempat keterampilan ini saling berhubungan dan saling menunjang satu sama lain. Hal itu disebabkan keempat aspek tersebut sangat penting. Keterampilan berbahasa merupakan keahlian yang harus dikuasai dan diberikan kepada masyarakat pada umumnya. Terdapat empat aspek keterampilan berbahasa yang tercakup dalam pengajaran bahasa, yaitu: (1) keterampilan menyimak; (2) keterampilan berbicara; (3) keterampilan membaca; dan (4) keterampilan menulis. Keempat keterampilan tersebut saling terkait satu dengan yang lain. Keterampilan berbahasa diawali dengan belajar menyimak atau mendengarkan, kemudian berbicara secara optimal.

Penerapan kurikulum terbaru kurikulum 2013 merupakan tonggak sebagai sarana evaluasi dan inovasi pembelajaran. Dalam kurikulum 2013 disebutkan bahwa salah satu tujuan mata pelajaran Bahasa Indonesia adalah siswa dapat berkomunikasi secara efektif dan efisien sesuai dengan etika yang berlaku, baik secara lisan maupun tertulis. Karangan eksposisi merupakan karangan yang menjelaskan atau memaparkan pendapat, gagasan, keyakinan, yang memerlukan fakta yang diperkuat dengan angka, statistik, peta dan grafik, tetapi tidak bersifat memengaruhi pembaca (Dalman, 2014: 120). Menulis eksposisi memerlukan organisasi secara hati-hati dalam penyajiannya supaya informasi yang disampaikan dapat dipahami pembaca dengan mudah. Informasi harus disusun dan disajikan secara logis, berurutan, dan terperinci. Akan tetapi, siswa dalam menulis karangan eksposisi seringkali menuliskan bahan tulisan secara acak sesuai dengan ide yang ada dalam pikiran siswa. Selain itu, seringkali siswa tidak menggunakan ejaan dengan benar dalam menulis eksposisi.

Pada proses pembelajaran, guru memegang peran sebagai fasilitator sekaligus pemain utama. Sanjaya (2008: 282) menyatakan bahwa sebagai fasilitator, guru berperan dalam memberikan pelayanan untuk memudahkan siswa dalam kegiatan proses pembelajaran. Keterampilan menulis siswa harus terus dibina dan dikembangkan untuk mendapatkan hasil tulisan yang baik, komunikatif, dan menarik. Pembelajaran menulis di sekolah bertujuan agar siswa mampu mengomunikasikan ide atau gagasan/ pendapat secara tertulis. Selain itu, pembelajaran menulis siswa diarahkan agar siswa mampu menuangkan pikiran, gagasan/ pendapat, maupun perasaan dalam bentuk bahasa tulisan secara benar. Kebenaran itu dapat dilihat dari segi kebahasaan, isi, dan makna.

Pada penelitian ini, pada kegiatan observasi awal dan pratindakan yang dilakukan pada siswa kelas X IPA 2 SMA Muhammadiyah 2 Cepu Kabupaten Blora tahun Ajaran 2017/2018 diketahui bahwa nilai hasil pembelajaran menulis teks eksposisi masih rendah atau belum memenuhi KKM, begitu pula proses pembelajarannya. Dari 23 siswa di kelas XIPA 2 masih banyak siswa yang memperoleh nilai di bawah KKM. Siswa yang memperoleh nilai 85 sebanyak 3 siswa, nilai 75 sebanyak 2 siswa, nilai 70 sebanyak 11 siswa, dan siswa yang memperoleh nilai $<70$ sebanyak 10 siswa. 
Menurut guru yang mengampu kelas tersebut hal tersebut disebabkan oleh beberapa faktor, diantaranya: (1) kurang antusiasnya siswa dalam mengikuti pelajaran menulis teks eksposisi; (2) siswa mengalami kesulitan dalam memahami materi menulis teks eksposisi; (3) siswa merasa jenuh atau bosan pada mata pelajaran bahasa Indonesia yang selama ini dilakukan secara monoton; (4) guru kesulitan membangkitkan keaktifan siswa; (5) guru belum menggunakan metode pembelajaran yang inovatif; (6) kurangnya pembimbingan guru saat siswa mengerjakan tugas menulis teks eksposisi; dan (7) guru kesulitan dalam menemukan dan menerapkan metode pembelajaran yang tepat dalam mengajar materi menulis teks eksposisi.

Keterampilan menulis eksposisi pada siswa kelas X IPA 2 SMA Muhammadiyah 2 Cepu Kabupaten Blora masih tergolong rendah. Faktor penyebab rendahnya keterampilan menulis eksposisi selain faktor dari siswa juga disebabkan faktor guru. Beberapa siswa belum paham tentang menulis karangan eksposisi dan siswa juga merasa kesulitan dalam menuangkan ide atau gagasannya. Selain itu, guru selama ini kurang memberikan contoh dan bimbingan tentang menulis eksposisi. Guru selama ini ketika mengajar lebih banyak berceramah dan pemberian tugas. Pembelajaran yang dilakukan selama ini lebih mementingkan hasil daripada proses. Pembelajaran yang seperti ini membuat siswa kurang tertarik dan merasa kesulitan untuk menulis.

Berdasarkan kondisi tersebut, guru perlu menggunakan sebuah metode sebagai pendukungnya untuk meningkatkan kualitas proses pembelajaran dan meningkatkan keterampilan siswa dalam menulis eksposisi. Adapun metode pembelajaran yang dipilih adalah metode pembelajaran kooperatif Team Assisted Individualization. Pemilihan metode Team Assisted Individualization karena merupakan metode yang menyenangkan dan memudahkan siswa untuk memecahkan setiap permasalahan yang dihadapi, dan sekaligus dapat mengembangkan keterampilan sosial siswa dalam kelompok.

\section{Metode Penelitian}

Metode penelitian yang digunakan dalam penelitian ini adalah deskriptif kualitatif. Subjek dalam penelitian ini adalah siswa kelas X IPA 2 SMA Muhammadiyah 2 Cepu Kabupaten Blora dengan Populasi kelas X. Sedangkan Sampel kelas X IPA 2 yang berjumlah 25 siswa dengan sampling secara Purposive. Sumber data tersebut meliputi peristiwa, informan yaitu Guru dan siswa kelas X IPA 2 SMA Muhammadiyah 2 Cepu Kabupaten Blora.

Teknik pengumpulan data yang digunakan adalah metode observasi, metode wawancara, metode tes dan metode dokumentasi. Teknik analisis data yang digunakan dalam penelitian tindakan kelas ini adalah teknik deskriptif kualitatif dan jenis penelitian tindakan kelas eksperimental. Teknik deskriptif kualitatif ini mencakup kegiatan untuk menguraikan tentang kualitas proses pembelajaran keterampilan menulis eksposisi dan menerapkan metode Team Assisted Indiviadualization untuk meningkatkan keterampilan menulis eksposisi. Kelemahan dan kelebihan kinerja guru dan kinerja siswa dalam pembelajaran. Hasil analisis tersebut kemudian dibahas bersama guru yang hasilnya dijadikan dasar penyusunan perencanaan tindakan tahap berikutnya sesuai dengan siklus yang telah direncanakan sebelumnya. Sedangkan deskriptif komparatif adalah (1) membandingkan kualitas proses pembelajaran sebelum dan 
setelah menerapkan metode Team Assisted Individualization pada pembelajaran. (2) membandingkan hasil nilai keterampilan menulis eksposisi siswa mulai siklus I sampai dengan siklus III.

\section{Hasil dan Pembahasan}

Menulis eksposisi merupakan salah satu kompetensi dasar yang harus dimiliki oleh siswa kelas $\mathrm{X}$. Untuk mencapai kompetensi tersebut, pemilihan metode dalam proses belajar mengajar yang menarik dan inovatif akan menentukan keberhasilan tujuan yang ingin dicapai dalam pembelajaran tersebut. Guru harus mampu memilih dan menerapkan metode secara efektif untuk mampu meningkatkan keterampilan menulis eksposisi siswa. Tindakan pada penelitian ini menggunakan metode pembelajaran Team Assisted Individualization pada pembelajaran menulis eksposisi. Keterampilan menulis merupakan cara seseorang dalam menuangkan gagasan atau ide ke dalam sebuah tulisan supaya orang lain dapat memahami dan mengerti informasi yang tertuang di dalamnya. Begitu pentingnya keterampilan menulis sehingga keterampilan menulis menjadi salah satu keterampilan berbahasa yang mendapat perhatian dalam pengajaran bahasa, khususnya bahasa Indonesia.

Kualitas proses dan hasil keterampilan menulis, khususnya menulis teks eksposisi ditentukan oleh peran guru sebagai perancang pembelajaran di dalam kelas. Guru yang mampu menerapkan model yang kreatif dan inovasi serta tidak keluar dari ranah pendekatan saintifik sebagaimana yang tercakup dalam kurikulum 2013, sangat berepengaruh terhadap keberhasilan pembelajaran. Upaya tersebut dilakukan oleh guru dan peneliti dengan meningkatkan keterampilan menulis teks eksposisi melalui penerapan metode Team Assisted Individualization dan penggunaan media gambar pada siswa kelas X IPA 2 SMA Muhammadiyah 2 Cepu Kabupaten Blora.

Guru harus pandai dalam memilih metode dan media yang digunakan dalam penelitian tindakan kelas. Melalui penerapan metode Team Assisted Individualization dan penggunaan media gambar, siswa memiliki pengalaman belajar yang berbeda, karena disuguhkan sebuah pemaparan masalah secara langsung. Pemanfaat metode dan media ini mampu meningkatkan kualitas proses dan hasil keterampilan menulis teks eksposisi. Hal tersebut dapat dilihat dari hasil penilaian proses dan nilai selama tindakan kelas berlangsung.

Penelitian tindakan ini dilaksanakan dua siklus. Setiap siklus dengan $2 x$ pertemuan atau $4 \times 40$ menit. Pertemuan pertama guru menerangkan materi menulis teks eksposisi, dan pengamatan terhadap contoh teks eksposisi. Pertemuan kedua siswa diminta untuk menuliskan teks eksposisi berdasarkan video yang telah disiapkan. Langkah tersebut memudahkan guru dan peneliti untuk mengamati dan menilai kinerja guru dan siswa serta keterampilan menulis teks eksposisi. Berikut akan dipaparkan pembahasan hasil penelitian.

\section{1) Peningkatan Kualitas Proses Pembelajaran Keterampilan Menulis Teks Eksposisi.}

Peningkatan keterampilan menulis teks eksposisi dinilai dari kinerja guru dan kinerja siswa selama pelaksanaan pratindakan, siklus I, dan siklus II. Berdasarkan hasil pengamatan selama proses pembelajaran, berikut diuraikan peningkatan kinerja guru dan kinerja siswa 
a) Peningkatan Kinerja Guru

Kinerja guru dalam pembelajaran keterampilan menulis teks eksposisi berdasarkan pada hasil penelitian guru dalam menyusun Rencana Pelaksanaan Pembelajaran (RPP) dan melaksanakan pembelajaran di setiap siklus. Hasil pengamatan dalam penyusunan RPP dari prasiklus, siklus I, siklus II dan siklus III selalu mengalami peningkatan. Pada prasiklus guru memperoleh skor 21 dengan nilai 52,5 (kurang). Siklus I nilai guru meningkat menjadi 29 degan nilai 69 (cukup). Pada siklus II dapat dikatakan bahwa guru sudah cukup baik dalam menyusun RPP sehingga memperoleh nilai 35 dengan nilai 77 (cukup baik) dan pada siklus IIII dapat dikatakan bahwa guru sudah sangat baik dalam menyusun RPP dengan nilai 80.

Pengamatan kinerja guru dalam pelaksanaan kegiatan belajar mengajar. Penilaian pada kegiatan ini terdiri dari beberapa aspek, yakni: (a) kegiatan prapembelajaran; (b) kegiatan pendahuluan; (c) kegiatan inti, meliputi penguasaan materi pembelajaran, penggunaan metode dan media, kegiatan pembelajaran, penilaian proses dan hasil, dan (d) kegiatan penutup.

b) Peningkatan Kinerja Siswa

Peningkatan kinerja siswa selama proses pembelajaran mulai dari prasiklus sampai siklus 3, aspek yang dinilai yaitu: (1) keaktifan siswa dalam pembelajaran;(2) perhatian dan konsentrasi terhadap penjelasan guru; dan (3) minat dan motivasi dalam pembelajaran. Berikut ini penjelasan dari aspek tersebut.

1. Keaktifan Siswa dalam Pembelajaran

Indikator ini meliputi siswa bersedia menjawab pertanyaan yang diberikan oleh guru, berani menanyakan tentang materi yang belum dipahami, berani menyampaikan pendapat, dan aktif dalam kegiatan diskusi. Pada survey awal, keaktifan siswa belum begitu terlihat, nilai rata-rata keaktifan siswa dalam survey awal mencapai 2,77 dengan persentase keberhasilan 55,38\%. Pada siklus I mengalami peningkatan keaktifan siswa di kelas dengan mencapai 3,08 dengan persentase keberhasilan $61,60 \%$. Pada siklus II, pembelajaran sudah mulai berubah. Siswa sudah mulai aktif dalam kegiatan pembelajaran. Nilai rata-rata keaktifan siswa di kelas dengan mencapai 4,06 dengan persentase keberhasilan $81,20 \%$. Adapun pada siklus III siswa sudah berani mengungkapkan gagasannya dan berani menanyakan materi yang belum dipahami

2. Perhatian dan Konsentrasi terhadap Penjelasan Guru

Pada survey awal, perhatian dan konsentrasi siswa dalam pembelajaran belum maksimal atau optimal, siswa masih terlihat ada yang bercakap-cakap dengan teman sebangkunya, siswa masih terlihat ada yang melamun, mengantuk, dan sibuk dengan aktivitas sendiri yang tidak mendukung jalannya pembelajaran. Pada prasiklus nilai rata-rata perhatian dan konsentrasi siswa mencapai 2,88 persentase keberhasilan $57,69 \%$. Pada siklus I mengalami peningkatan dari sebelumnya, nilai rata-rata perhatian dan konsentrasi siswa mencapai 3,15 dengan persentase keberhasilan 63\%. Pada siklus III terjadi peningkatan apabila dibandingkan dengan siklus I dan siklus II. Siswa sudah terlihat 
memperhatikan penjelasan dari guru. Nilai rata-rata perhatian dan konsentrasi siswa mencapai 3,71 dengan persentase keberhasilan $74,20 \%$.

3. Minat dan Motivasi dalam Pembelajaran

Indikator ini meliputi semangat siswa dalam mengikuti pembelajaran, antusias, dan menunjukkan kesungguhan dalam pembelajaran. Pada survey awal, siswa terlihat tidak bersemangat, kurang antusias, dan tidak menunjukkan kesungguhan dalam pembelajaran. Pada siklus I mengalami peningkatan dari sebelumnya, nilai rata-rata minat dan motivasi siswa mencapai 3,06 dengan persentase keberhasilan 61,20\%. Pada siklus II minat dan motivasi siswa

\begin{tabular}{lllccc}
\multicolumn{6}{l}{ Tabel 1. Rekapitulasi Persentase Keberhasilan Kinerja Siswa } \\
\hline No & Indikator & \multicolumn{3}{l}{ Porsentase yang dicapai } & \\
\cline { 3 - 6 } & & $\begin{array}{l}\text { Kondisi } \\
\text { Awal }\end{array}$ & Siklus I & Siklus II & Siklus III \\
\hline 1. & $\begin{array}{l}\text { Keaktifan siswa } \\
\text { dalam proses } \\
\text { pembelajaran }\end{array}$ & 55,38 & 61,60 & 76,20 & 82,54 \\
\hline 2. & $\begin{array}{l}\text { Perhatian dan } \\
\text { Konsentrasi siswa } \\
\text { dalam pembelajaran }\end{array}$ & 57,69 & 63 & 74,20 & 80,25 \\
\hline 3. & $\begin{array}{l}\text { Minat dan motivasi } \\
\text { siswa dalam } \\
\text { pembelajaran }\end{array}$ & 52,31 & 61,20 & 73,40 & 81,30 \\
\hline
\end{tabular}

\section{2) Peningkatan Keterampilan Menulis Teks Ekposisi}

Peningkatan keterampilan menulis teks eksposisi siswa dapat dinilai melalui hasil tes siswa. Berdasarkan hasil pengamatan dan penilaian, nilai keterampilan menulis teks eksposisi siswa kelas X IPA 2 SMA Muhammadiyah 2 Cepu selalu mengalami peningkatan dari prasiklus sampai siklus III. Jumlah siswa yang mencapai KKM selalu menunjukan peningkatan di setiap siklus. Adapun indikator ketercapaian dalam keterampilan menulis eksposisi siswa dalam penelitian ini sebagai berikut.

a) Isi

Pada kondisi prasiklus, siswa masih kesulitan dalam mengembangkan ide atau gagasan setelah siswa membuat kerangka karangan yang telah dibuat. Ide atau gagasan siswa masih bersifat terbatas. Pada siklus I siswa sudah mulai dapat mengembangkan ide dan gagasan berdasarkan tema yang ditentukan sendiri. Pada siklus II kemampuan dalam pengembangan gagasan siswa sudah meningkat, tulisan yang dihasilkan isinya sudah cukup. Kemudian, untuk meningkatkan lagi, peneliti melaksanakan siklus III. Pada siklus III kemampuan siswa dalam mengembangkan gagasannya sudah baik dan substansinya tentang permasalahan yang terdapat pada gambar juga sudah bagus

b) Organisasi

Berdasarkan hasil analisis terhadap tulisan siswa dari prasiklus hingga siklus II tampak adanya peningkatan keterampilan menulis eksposisi siswa dalam mengorganisasikan isi tulisan. Pada prasiklus, sisswa belum mampu mengorganisasikan isi dengan baik atau gagasan masih dalam kategori kurang lancar. Pada prasiklus, diketahui nilai rata-rata aspek organisasi isi sebesar 2,31. Pada siklus I mengalami peningkatan menjadi 3 , dan siklus II juga mengalami 
peningkatan menjadi 3,04. Adapun pada siklus III nilai rata-rata aspek ini menjadi 3,16 .

c) Kosakata

Berdasarkan hasil analisis terhadap tulisan siswa pada prasiklus ditemukan ketidaktepatan pemilihan kosakata. Peningkatan penggunaan kosakata dapat dilihat dari hasil rata-rata yang diperoleh siswa. Perolehan nilai rata-rata aspek ini pada prasiklus sebesar 2,39, sedangkan siklus I meningkat menjadi 2,76. Adapun siklus II mengalami peningkatan rata-rata sebesar 3. Dan siklus III juga mengalami peningkatan rata-rata sebesar 3,50.

d) Pengembangan Bahasa

Peningkatan pengembangan bahasa dapat dilihat dari hasil rata-rata yang diperoleh siswa. Pada prasiklus diketahui bahwa nilai rata-rata aspek pengembangan bahasa sebesar 2,15 , sedangkan pada siklus I dan siklus II mengalami peningkatan rata-rata menjadi 2,48, siklus II menjadi 2,84 sedangkan siklus III mengalami peningkatan menjadin 3,50

e) Mekanik

Aspek mekanik tulisan siswa pada prasiklus masih banyak kesalahan, khususnya mengenai pemakaian ejaan. Selain itu, siswa juga masih sering salah dalam penulisan huruf kapital, tanda baca, penulisan kata baku, dan pembentukan kata. Pada prasiklus, nilai terendah yang dicapai siswa sebesar 45 , sedangkan nilai tertinggi yang dicapai sebesar 75 , dan nilai rata-rata mencapai 57,12 . Peningkatan siklus I mengalami peningkatan, nilai terendah yang dicapai siswa sebesar 60 , sedangkan nilai tertinggi yang dicapai siswa sebesar 80 , dan nilai rata-rata mencapai 70,2. Pada siklus II mengalami peningkatan, nilai terendah yang dicapai siswa sebesar 70 , sedangkan nilai tertinggi yang dicapai sebesar 85 , dan nilai ratarata siswa mencapai 74 .

Tabel 2. Nilai Terendah, Nilai Tertinggi, dan Nilai Rata-rata Keterampilan Menulis Eksposisi

\begin{tabular}{|c|c|c|c|c|}
\hline No & Kegiatan & Nilai Tertinggi & Nilai Terendah & Nilai Rata-rata \\
\hline 1. & Pratindakan & 70 & 45 & 26,9 \\
\hline 2. & Siklus I & 75 & 55 & 28,8 \\
\hline 3. & Siklus II & 80 & 65 & 30,8 \\
\hline 4. & SIklus III & 85 & 66 & 32,7 \\
\hline
\end{tabular}

setelah menyimak/ mendengar, berbicara, dan membaca. Hal ini sesuai yang diungkapkan Nurgiyantoro (2013: 422) bahwa "aktivitas menulis merupakan suatu bentuk manifestasi kompetensi berbahasa paling akhir dikuasai pembelajar bahasa setelah kompetensi mendengarkan, berbicara, dan membaca". Menulis eksposisi merupakan salah satu kompetensi dasar yang harus dimiliki oleh siswa kelas $X$. Untuk mencapai kompetensi tersebut, pemilihan metode dalam proses belajar mengajar yang menarik dan inovatif akan menentukan keberhasilan tujuan yang ingin dicapai dalam pembelajaran tersebut. Guru harus mampu memilih dan menerapkan metode secara efektif untuk mampu meningkatkan keterampilan menulis eksposisi siswa. Tindakan pada penelitian ini menggunakan metode pembelajaran Team Assisted Individualization pada pembelajaran menulis eksposisi.

Pengaruh Motivasi Belajar dan Kemampuan Berpikir Logis... (Etik Yuliana Prasetyaningrum) 
Penerapan metode pembelajaran TeamAssisted Individualization ini menjadikan siswa lebih aktif dalam mengikuti proses pembelajaran. Siswa dilatih secara intensif dan berkesinambungan dalam menulis eksposisi. Siswa juga dilatih untuk mengembangkan pengetahuan dan pemahaman melalui belajar kelompok. Siswa diberi latihan lanjutan pada situasi yang lebih kompleks dengan pemberian latihan mandiri yakni menulis eksposisi secara individu berbasis media gambar. Siswa menjadi lebih terlatih untuk menguasai berbagai aspek yang terkandung dalam eksposisi dengan mendapat bimbingan guru dalam praktik terstruktur dan mandiri. Kegiatan pembelajaran yang telah dilakukan dengan menerapkan metode pembelajaran Team Assisted Individualization memberikan dampak positif terhadap keberhasilan pembelajaran.

Penggunaan metode pembelajaran Team Assisted Individualization dalam pembelajaran keterampilan menulis karangan eksposisi diharapkan dapat meningkatkan keterampilan. Menurut Suprihatiningrum (2013: 212) model pembelajaran kooperatif tipe ini menekankan bahwa individu yang belum memahami materi merupakan tanggung jawab anggota kelompok lain. Berdasarkan hasil pengamatan atau observasi dan analisis pada siklus I, siklus II dan siklus III pembelajaran menulis eksposisi mengalami peningkatan. Peningkatan mencakup peningkatan kualitas proses pembelajaran dan peningkatan keterampilan menulis eksposisi siswa. Apabila dikaitkan dengan penelitian terdahulu, penggunaan metode pembelajaran Team Assisted Individualization juga ditemukan dalam penelitian yang dilakukan oleh Sabarun (2011) menyatakan bahwa metode kooperatif sangat efektif untuk meningkatkan keterampilan menulis siswa. Hal ini bisa dilihat dari peningkatan prestasi menulis siswa. Dengan demikian, terbukti bahwa metode pembelajaran kooperatif dapat meningkatkan hasil belajar siswa. Metode pembelajaran kooperatif memberikan solusi berkaitan dengan kemampuan kognitif siswa. Siswa menjadi lebih mampu menguasai konsep-konsep dasar dalam pembelajaran menulis. Penelitian terkait lainnya yakni penelitian yang dilakukan oleh Guerra (2010) siswa menganggap menulis sebagai salah satu kegiatan yang terbatas yang menuntut mereka tidak banyak melakukan aktivitas. Siswa masih merasa kesulitan dalam mengekspresikan suatu hal ke dalam bentuk tulisan. Penguasaan tata bahasa yang leluasa memungkinkan untuk mengekspresikan diri ke dalam tulisan secara jelas dan akurat.

Pembelajaran dengan menerapkan metode pembelajaran Team Assisted Individualization yang dilakukan pada siswa dalam pembelajaran menulis eksposisi membuat siswa lebih aktif dan bersemangat dalam mengikuti pembelajaran. Hal tersebut memberikan dampak pada kegiatan menulis siswa yang juga lebih baik. Siswa tidak mengalami kesulitan selama proses menulis eksposisi berlangsung. Hal ini sesuai dengan penelitian yang dilakukan oleh Sapkota. Sapkota menyatakan bahwa pada awalnya bahwa kegiatan menulis merupakan kegiatan yang termasuk sulit. Berbagai kendala muncul sehingga kegiatan menulis di kelas dialihkan menjadi kegiatan menulis yang dilakukan mandiri dalam bentuk penugasan individu, yakni pekerjaan rumah dengan memunculkan alasan karena alokasi pembelajaran bagi siswa yang terbatas dalam belajar menulis di kelas sehingga pada akhirnya siswa merasa tidak memeroleh bimbingan penuh dari guru. Hal tersebut berujung pada minat siswa yang cenderung lebih menyukai kegiatan berbicara daripada kegiatan menulis. Setelah dilakukan tindakan, siswa diuji dalam bentuk pemberian tes individu. Pemberian tindakan tersebut

Linguista Vol. 3, No. 1, Juni 2019: 1-11 
memberikan pengaruh positif, siswa dapat melakukan kegiatan menulis dengan baik di kelas tanpa mengalami kesulitan.

Pelaksanaan pembelajaran konvensional yang dilakukan oleh guru bahasa Indonesia pada sebelumnya tidak membuat siswa memperoleh pembelajaran yang menyenangkan, hal tersebut berdampak pada proses dan hasil pembelajaran siswa. Oleh sebab itu, metode pembelajaran Team Assisted Individualization sebagai salah satu metode pembelajaran kooperatif yang dapat memberikan pengalaman belajar menyenangkan bagi siswa. Siswa memperoleh pengalaman belajar terpadu berbasis sosial.

Pembelajaran kooperatif yang diwujudkan dalam tim belajar sebagai tantangan bagi siswa untuk ikut berperan serta aktif dan bertanggung jawab sebagai anggota kelompok belajar. Siswa dengan kemampuan bahasa yang tinggi akan dapat membantu siswa yang kemampuan bahasanya rendah. Selain itu, pembelajaran kooperatif juga mampu menumbuhkembangkan keterampilan sosial melalui kegiatan belajar kelompok bersama teman sejawat.

Wacana eksposisi sangat penting dalam proses pendidikan, terutama pada jenjang SMA. Hal ini disebabkan wacana eksposisi merupakan salah satu cara untuk mengetahui sejauh mana produksi bahasa alami pada remaja Selanjutnya, penelitian yang dilakukan oleh Aldana (2005). Hasil peneliti menunjukkan bahwa menerapkan pembelajaran kooperatif dapat meningkatkan sikap siswa terhadap tugas menulis dan memperoleh kemahiran yang lebih tinggi dalam keterampilan menulis. Penerapan cooperative learning sangat efektif karena tidak ada siswa yang mendominasi dalam pembelajaran. Para siswa saling bekerjasama satu dengan yang lain untuk mengerjakan tugas kelompok yang diberikan oleh guru sehingga tujuan pembelajaran dapat tercapai.

Pada penelitian ini kegiatan pembelajaran menulis eksposisi menerapkan metode pembelajaran Team Assisted Individualization. Penelitian ini dilaksanakan dalam tiga siklus. Keunggulan penelitian ini terletak pada serangkaian tahapan pembelajaran yang mampu memberikan stimulus pembelajaran dan mampu mengembangkan, serta meningkatkan keterampilan siswa dalam menulis eksposisi.

Penerapan metode pembelajaran Team Assisted Individualization benar-benar dapat meningkatkan keterampilan siswa dalam menulis. Hal tersebut sesuai dengan pernyataan ahli, Daryanto (2013:418) menyatakan bahwa Team Assisted Individualization merupakan metode yang mengombinasikan keunggulan pembelajaran kooperatif dan pembelajaran individu. Penggunaan metode pembelajaran Team Assisted Individualization sebagai salah satu pendukung pembelajaran akan sangat membantu guru dalam menyampaikan materi ajar serta menjelaskan berbagai kendala siswa dalam memahami metari ajar yang disampaikan oleh guru. Pada penelitian ini menggunakan metode pembelajaran Team Assisted Individualization. Siswa yang kesulitan menyampaikan ide dalam menulis eksposisi, dengan mudah mengembangkan ide. Sebagai metode pembelajaran, Team Assisted Individualization memiliki karakteristik tahapan pembelajaran serta penggunaan media pembelajaran. Pemanfaatan tahapan pembelajaran dan pemilihan media pembelajaran yang inovatif dan tepat akan mampu merangsang perubahan sikap dan perilaku siswa, peningkatan keterampilan menulis eksposisi, serta minat dan motivasi siswa.

Berdasarkan hasil pengamatan dan analisis pada prasiklus, siklus I, siklus II dan siklus III dapat disimpulkan bahwa pembelajaran menulis eksposisi dengan menerapkan

Pengaruh Motivasi Belajar dan Kemampuan Berpikir Logis... (Etik Yuliana Prasetyaningrum) 
metode pembelajaran Team Assisted Individualization dengan media gambar pada siswa kelas X IPA 2 SMA Muhammadiyah 2 Cepu Kabupatern Blora mengalami peningkatan pada proses dan hasil belajar siswa dalam menulis eksposisi.

\section{Kesimpulan}

Secara singkat simpulan hasil penelitian ini yaitu terdapat peningkatan kualitas proses pembelajaran dan keterampilan pembelajaran menulis eksposisi pada siswa kelas X IPA 2 SMA Muhammadiyah 2 Cepu Kabupaten Blora. Simpulan hasil penelitian dengan menggunakan metode Team Assisted Individualization sebagai berikut:

1. Penerapan metode Team Assisted Individualization dapat meningkatkan kualitas proses pembelajaran keterampilan menulis eksposisi siswa kelas X IPA 2 SMA Muhammadiyah 2 Cepu Kabupaten Blora dengan indikator ketercapaian (1) Penilaian kinerja siswa siswa yang mencakup tiga aspek, yaitu: (a) keaktifan siswa dalam pembelajaran; (b) perhatian dan konsentrasi siswa dalam pembelajaran; dan (c) minat dan motivasi siswa dalam pembelajaran. Nilai rata-rata kinerja siswa pada siklus 1 mencapai 9,29 (61,93\%) dengan kriteria cukup, nilai rata-rata kinerja siswa pada siklus 2 mencapai 11,44 (76,27\%) dengan kriteria baik. (2) Penilaian terhadap kinerja guru dengan aspek sebagai Pengamatan kinerja guru dalam pelaksanaan kegiatan belajar mengajar. Penilaian pada kegiatan ini terdiri dari beberapa aspek, yakni: (a) kegiatan prapembelajaran; (b) kegiatan pendahuluan; (c) kegiatan inti, meliputi penguasaan materi pembelajaran, penggunaan. metode dalam kegiatan pembelajaran.

2. Penerapan metode Team Assisted Individualization dapat meningkatkan keterampilan menulis eksposisi. Hal ini ditandai dengan besarnya persentase kelulusan siswa. Persentase tersebut mengalami peningkatan pada setiap siklusnya. Pada survei awal persentasekelulusansiswa hanya sebanyak 3 siswa $(11,53 \%)$, pada siklus I naik menjadi 10 siswa (40\%) dan siklus II mencapai 15 siswa (60\%), Peningkatan kualitas proses pembelajaran menulis eksposisi berpengaruh pada kenaikan keterampilan menulis eksposisi. Hal ini sangat wajar karena keterbatasan intelektual seseorang dan berdasarkan kemampuan seseorang memang tidak mungkin bisa ditingkatkan secara cepat, tetapi membutuhkan proses yang panjang.

\section{Daftar Pustaka}

Alwasilah, A. dan Alwasilah, S. (2007). Pokoknya Menulis Cara Baru Menulis dengan Metode Kolaborasi. Bandung: Kiblat.

Arikunto, S. (2007). Penelitian Tindakan Kelas. Jakarta: Bumi Aksara.

Arikunto, S. (2010). Prosedur Penelitian suatu Pendekatan Praktik. Jakarta: Rineka Cipta.

Dalman. (2014). Keterampilan Menulis. Jakarta: Rajawali Press.

Danim. (2013). Karya Tulis Inovatif. Bandung: PT Remaja Rosdakarya.

Daryanto. (2011). Media Pembelajaran. Bandung: Satu Nusa.

Kusumaningsih, dkk. (2013). Terampil Berbahasa Indonesia. Yogyakarta: CV Andi.

Hamdani. (2011). Strategi Belajar Mengajar. Bandung: Pustaka Setia. 
Marahimin (2004). Menulis secara Populer. Jakarta: Pustaka Jaya.

Pamungkas. (2012). Bahasa Indonesia dalam Berbagai Perspektif. Yogyakarta: Andi Offset.

Sabana, M dan Sunarti. (2005). Strategi Belajar Mengajar Bahasa Indonesia Berbagai Pendekatan, Metode dan Media Pengajaran. Bandung: Pustaka Setia.

Slamet, St. Y. (2009). Dasar-dasar Keterampilan Menulis. Surakarta: UNS Press.

Slavin, S. (2009). Cooperative Learning. Bandung: Nusa Media.

Sugiyono. (2010). Metode Penelitian Kuantitatif, Kualitatif dan R \& D. Bandung: Alfabeta.

Syah. (2011). Psikologi Pendidikan dengan Pendekatan Baru. Bandung: PT Remaja Rosdakarya. 